\title{
ISLAMIC METHODOLOGY OF MOTIVATION: AN APPRAISAL IN THE LIGHT OF SEERAH
}

\author{
${ }^{*}$ Dr. Amir Hayat \\ Assistant Professor, Department of Islamic Studies, \\ The University of Lahore, Sargodha Campus, Pakistan \\ ${ }^{* *}$ Muhammad Tariq Ramzan \\ Lecturer, Department of Islamic Studies, \\ The University of Lahore, Sargodha Campus, Pakistan \\ VERSION OF RECORD
}

Received: 25-Aug-19 Accepted: 12-Nov-19

Online/Print: 31-Dec-19

\begin{abstract}
The recent developments observed in the world are owed to the efforts of human capacities and capabilities. Zeal, flair and enthusiasm of work people keep the pace of development in steady mode. However, over a period of time, human motivation to work starts decreasing. In the western world studies have been carried out to find out factors which affect human motivation to devise strategies to enhance work motivation among individuals. It has been observed that determinants of motivation are cultural specific. Moreover it is associated with the world view of human being. Islam is distinguished religion from other religions of the world and forms its own culture. Holy Prophet Muhammad (SAW) in his life time prepared a group of individuals who changed the socio-political scene of this world in few years. Their motivation level was un-parallel to anyone else. The current study explores methodologies of motivation used by the Prophet (SAW) to stimulate his companions. The originality and value of this study can be seen in the sense that it will provide basis for the formulation of motivational framework based on Islamic teachings. As a conclusion, team of researchers comprising of educationists, social scientists, and Islamic scholars must work together to find out framework of motivation in the present day environment.

Keywords: Motivation, Methodology, Human beings, Individuals, Seerat.

To Cite this Article:

Hayat, D. A., \& Ramzan, M. T. (2019). ENGLISH: ISLAMIC METHODOLOGY OF MOTIVATION: AN APPRAISAL IN THE LIGHT OF SEERAH. İQĀN, 2(03), 1-22.
\end{abstract}




\section{Introduction:}

Life has been in state of development from its beginning. Life style of man has changed from Stone Age to the modern digital age. The pace of human development has been consistent for a long period of time. However, from the last two centuries the speed of technological advancement has been multiplied many times than in the past. Since the famous 'industrial revolution' in late seventeenth and early eighteenth century, the world has progressed in such a way that is unprecedented. The world has developed in many ways and directions. It has developed socially, economically, technologically. There are number of factors that have contributed in the development of world but the most important and decisive factor is man himself. Without competent, motivated and energetic people no organization or nation can progress. ${ }^{1}$

Total number of human capacities and capabilities available in a country are called intangible resources or human resources. ${ }^{2}$ As compared to physical resources human resources have more capacity to enhance their efficiency and productivity. The capacities and capabilities of human resources can be enhanced through investment in their development through better education, health facilities, proper living conditions, and through motivation. A man is motivated to work by expected rewards and fear of losing some benefits. Various researches have been carried out to develop a set of incentives to be offered to the people to enhance their capacities and capabilities. The needs and expectations of individuals from their employer depend upon their world view. The modern world view adopted in developed countries is based upon materialism. The people believing in materialistic world view are motivated by the fulfillment of worldly needs of life. The goal of material world view is achievement of happiness and material good. The philosophy of materialism and secularization of knowledge has affected motivation theories in great context. Such practices are formulated that motivate people through fulfillment of their material needs. The difference in world view of people brings difference in their preferences and needs. The people who believe only this world are motivated merely by worldly necessities and comforts. On the other hand, the people who believe in different world view their needs and aspirations become different.

\footnotetext{
${ }^{1}$ Sison. Payos \& Zorilla, Personnel Management in the 21 ${ }^{\text {st }}$ Century, (Quezan City: PMA PRP Company, Inc., 2003), p:8

2 De Cenzo, D. A. \& Robbins, S. P., Fundamentals of Human Resource Management, (New Delhi: John Wiley and Sons, Inc., 2005), p:2
} 
$\bar{I} Q \bar{A} N$ : Vol: 02, Issue: 03, Dec 2019

Islam presents a world view that is different from materialistic world view. Islam believes in the un-seen God (Allah Almighty) and fragile nature of this world. Islam views this world a temporal place of living for human beings and hereafter as the final goal. Moreover it presents the concept of 'Final Judgment' where all actions of human beings are weighted and rewarded accordingly. This world view totally changes the behavior of Muslims in this world. Muslims view this world as a temporary place of living where they are sent to perform according to the Will of Allah and in return earn the blessed life of the hereafter. Moreover, modern motivational theories envisage leadership as a strong source of motivation for the followers. The conduct of leadership determines the behavior of his followers. A leader is viewed more effective and successful as many people follow him and take inspiration from him. In Islamic faith the best leader is the Prophet Muhammad $(S A W)$. The Quran clearly declares him the perfect example for the Muslims. The personality of Prophet Muhammad is the greatest source of motivation for the Muslims. He is not only true example for the past but for the present, and not only for the present generations but also for the generations to come. Islamic world view and Prophet Muhammad (SAW) as a leader and true example for the Muslims demand a fresh framework of motivation in the light Islamic teachings.

\section{Literature Review:}

Although motivation from an Islamic perspective is new to the field of Islamic studies, however, valuable contributions have been made on this topic. The initial attempt to study human motivation from an Islamic perspective was made by Muhyid-Din Shakoor in 1978. ${ }^{1}$ Alwaneh's work entitled 'Human Motivation: An Islamic Perspective' in 1999 is another notable research carried out to identify the principles of motivation in Islam. ${ }^{2}$ The recent trends in the study of motivation from an Islamic perspective are clearly shifted towards the organizational context of motivation theory. ${ }^{3}$ Organizational behavior and motivation in organizational context has been subject of study and debate, however, study of motivation in the light of Seerah (SAW) is neglected dimension. To fill this research gap current study is carried out to elaborate Prophetic methodology of

\footnotetext{
${ }^{1}$ Shakoor, Muhyi-ud-Dīn, Toward an Islamic Motivational Psychology, (New York: Prentice Hall, 1978), p: 45

${ }^{2}$ Alwaneh, S. F., Human Motivation: An Islamic Perspective, the American Journal of Islamic Social Science, 15 (4). (1999), PP: 19-39

3 for example: Ali Abbas, J., Levels of Existence and Motivation in Islam, Journal of Management History, 15 (1). (2009), PP: 50-65; Ahmad Abdel Rahman, An Islamic Perspective on Organizational motivation, The American Journal of Islamic Social Sciences, 12 (2). (1995), PP: 185-203
} 
motivation so that modern world challenges could be addressed keeping in front the world views of Islam and attainment of the final goal of "Pleasure of Allah".

\section{Modern Concept of Motivation:}

The term motivation has become significant during the recent past. Human activities are driven by certain needs. All human beings are prompted by these needs to behave in a certain way. These human needs are considered as motivating factors of human beings. Motivation is psychological phenomenon that reflects an individual's desire to behave and willingly consume his efforts to achieve individual and collective goals. It is willingness of action especially in behavior. Moreover, it denotes an incentive or reason for doing something. The word motivation is derived from Latin which means "to move". According to Oxford Advanced Learner's Dictionary the word motive is a noun that reflects a reason for doing something, as mentioned below:

"Motivation denotes the reason why somebody does something or behaves in a particular way. To motivate is the process to make somebody want to do something, especially something that involves hard work and effort." 1

In the terminology of psychology, motivation represents;

"The psychological processes that are goal oriented in the human beings." 2

Motivation is in essence an emotional desire which drives a human being toward a positive direction to achieve specified goals. The goals of an individual may vary from monetary rewards, recognition or inner satisfaction. Motivation actually represents a propelling force that enhances enthusiasm and persistence to continue a course of action. This way of looking into process of motivation reveals the fact that motivational behavior is a goal directed behavior. Therefore, the motivation may be expressed as a process of stimulating goal directed behavior. In concrete words the motivation is:

"The driving force behind behavior that leads us to pursue some things and avoid others." ${ }^{3}$

Many factors affect the behaviors of human beings. These factors are called determinants of motivation. Important determinants of motivation include unconscious intents, skills, capacities and capabilities of individuals to perform

${ }^{1}$ Oxford Advanced Learner's Dictionary, (Oxford: Oxford University Press, 2010), p: 995

2 Abbas, J. Ali \& David Weir, Islamic Perspectives on Management and Organization, Journal of Management, Spirituality \& Religion, 2 (3). (2005): PP: 412

${ }^{3}$ Peter S. Westwood, Learning and Learning Difficulties, (Victoria: ACER Press, 2004), p:31 
$\bar{I} Q \bar{A} N$ : Vol: 02, Issue: 03, Dec 2019

specified task or pursue a path of action. As a result of these factors the motivation process determines the emphasizing value of a result of an action. For this purpose human beings adopt a certain pattern of life and avoid other behaviors. They give priority to some actions over the other at a particular time. Why people behave differently and what makes them most motivated and other related questions have been part of debate for a long time. Different people have tried to answer these questions through their research. A brief account of these theories is given below:

\section{Bureaucratic Theories of Motivation (Taylorism):}

In the bureaucratic theory of motivation, it is assumed that an individual's behavior is guided by seeking pleasure and avoiding pain. ${ }^{1}$ The bureaucratic model uses two different approaches to motivate people; on the one hand it uses material rewards such as pecuniary and non-pecuniary benefits to motivate people, and on the other hand it creates fear through material punishments such as demotion and dismissal to motivate people to achieve organizational goals. This theory has its foundations on pure economic self-interest and material gains and losses. ${ }^{2}$ Later on studies showed that material rewards and punishments are not sufficient to motivate in all circumstances. ${ }^{3}$ It reveals a fact that, economic self-interest is an inadequate factor which is not sufficient to describe source of human motivation. The inadequacy of bureaucratic or materialistic theory of motivation serve basis for further research in motivation theory and new theories emerged that are termed as content theories of motivation.

\section{Content Theories of Motivation:}

Content theories are group of motivational theories that focus on individual's needs as the source of motivation. Maslow and Herzberg are motivation theorists who explained human motivation on the basis of their needs. They assume that everyone is motivated by something that is common between all individuals. To them, there is one best way to motivate all people on the basis of needs of an individual. Ibrahim H. Maslow presented his famous hierarchy of needs theory suggesting certain sequence of needs. Physiological (food, drink, shelter), safety (security and protection of physiological needs), and social (acceptance, friendship, love) needs are basic needs. Self-esteem (self-respect, status), and selfactualization (need for growth and self-fulfillment) considered as higher level needs. According to this theory, a person moves on to the next level of needs and

\footnotetext{
${ }^{1}$ This concept is denoted as hedonistic view of man. For details:

Edgar H. Schen, Organizational Psychology, (Englewood Cliffs.: Prentice-Hall, 1988), p: 52

${ }^{2}$ Amitai Etzioni, Modern Organizations, (Englewood Cliffs: Prentice-Hall, 1964), p: 21-22

${ }^{3}$ Sison, Payos \& Zorilla, Personnel Management in the $21^{\text {st }}$ Century, p: 7
} 
seek further fulfillment once his basic needs are satisfied. Herzberg extended the Maslow's theory and makes it more directly applicable to work situation. His theory has been labeled as two-factor theory. According to Herzberg there are two different sets of factors which affect a person's motivation and job satisfaction; hygiene and satisfiers. Hygiene factors are related to good work relations with colleagues, good pay and working conditions. On the other hand, satisfiers related to content of one's job, nature of work, possibility of growth, job advancement, recognition and status. Crux of content theories is that only high salary does not motivate people, other work related incentives are necessary to motivate people.

\section{Process theories of motivation:}

Process theories of motivation consist on equity, expectancy and goal-setting theory. Equity theory is based upon the assumption that people want to be treated fairly. It the employees believe that the organizational reward system is fair and they are adequately rewarded for their work. Their motivation level maintains which result in consisting output. Expectancy theory states that employees are motivated by the expected rewards for hard work. The effort level of employees will become high if they believe that they would be appraised well, followed by rewards such as bonus, increment, promotion or appreciation letter. In simple words expectancy theory means people are motivated by calculating how much they can get from hard work? Goal setting theory believes that people are motivated by the higher goals. The theory concludes that specific goals enhance performance of people. With harder goal setting higher level of output could be achieved. The goals act as an internal motivator to stimulate people for more work. ${ }^{1}$ It is believed that goal setting is one of the most influential theories of work motivation that is applicable to all cultures.

\section{Modern Theory of Motivation:}

Nohria, Groysber and Lee have argued that modern theory of motivation is an advanced approach in comparison over earlier theories. The Modern Theory of Motivation utilizes experiences of brain science psychologists and scientists to understand human psychology through the application of direct brain observation.

The perspective of motivation theories varies from an Islamic point of view. The aforementioned theories of motivation refer to the extrinsic and intrinsic factors that force individuals towards a certain behavior. Impact of religion on behaviors

${ }^{1}$ Locke, E. A., Toward a Theory of Task Motivation and Incentives, Organizational Behavior and Human Performance, 3 (2). (1968), PP: 157-189 
$\bar{I} Q \bar{A} N$ : Vol: 02, Issue: 03, Dec 2019

of people has been considered outside the focus of these theories. In the West, religion is considered as a cultural phenomenon invented to coordinate human activities. It is concerned with the fulfillment of social order and the necessity of esteem and self-actualization. ${ }^{1}$ Modern trends in the Western society are secular based and mostly anti-religion. However, some voices are emerging in favor of studying the role of religion in human motivation. Religion plays vital role in motivating human beings. Many authors have elaborated religion as motivating factor in human activities. Israela Silberman a researcher in the field of psychology and religion, argues that "adhering to religious rules can also influence an individual's behavior, emotions and thinking." 2 To study the role of Islam on human motivation, there is need to understand the motivation in perspective of Islam.

\section{Concept of Motivation in Islam:}

The modern theories of motivation recognize physiological and psychological motives as the only source of motivation. Physiological motives are those primary motives related to basic human needs such as hunger, thirst, and quality of living. As for as psychological motives are concerned they include secondary motives such as achievement, affiliation, exploration and control. The primary and secondary sets of motives complement each other and form a complete set of motivational framework. ${ }^{3}$

However, Islam does not see human needs and aspirations in such a way. Islamic perspective about man and his psychobiological needs is different from that of modern secular materialistic point of view. Islamic ideology views man as special creation that enjoys extra ordinary status in the universe. Islam regards man to be the focus and central object of this universe. ${ }^{4}$ Islam believes in the dignity and honour of human beings. ${ }^{5}$

Holy Quran being the basic source of guidance in Islam provides important information about the human personality that is hard to gain merely by reason

${ }^{1}$ Porter, Brian \& Vander Veen, Steve, Motivation from a Christian Perspective, the Journal of Biblical Integration in Business, 1 (1). (2011), PP: 32

${ }^{2}$ Israela Silberman, Spiritual Role Modeling: The Teaching of Meaning Systems, International Journal for the Psychology of Religion, 15 (3). (2005), PP: 182

${ }^{3}$ Barker, L. M., Learning and Behavior: A Psychobiological Perspective, (New York: MacMillan, 1994), p: 56

${ }^{4}$ Naqvi, Nawab Haider, Syed, Ethics and Economics: An Islamic Synthesis, (Leicester: The Islamic Foundation, 1981), p: 45

${ }^{5}$ Mūsa Sadr, Sayyid, Islam: Humanity and Human Values, (Ahlul Bayt World Assembly, 2011), 11 (4). PP:37 
and intellect. According to Holy Quran man is created in finest and excellent of moulds. ${ }^{1}$ While describing the creation of man Holy Quran informs:

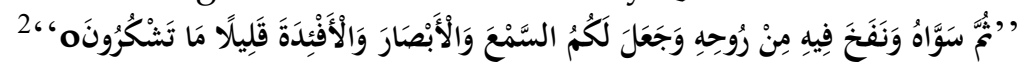

"Then He gave him a proportioned shape, and breathed into him of his spirit. And He granted you the (power of) hearing and the eyes and the hearts. Little you give thanks."

From this verse of Surah Al-Sajdah, it becomes clear that man is constituent of opposite elements; clay and soul. Clay is physical component and soul is nonphysical element with Divine attributes. ${ }^{3}$ Spirit of Allah pushes man towards highness and physical part of man tends towards inferiority. ${ }^{4}$ The Holy Quran states:

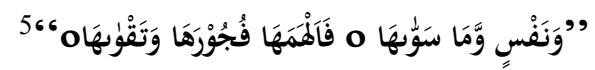

"And by the soul, and the One who made it well, then inspired it with its (instincts of) evil and piety"

There is tendency in man to do good and evil at the same time. Moreover, he is Allah Almighty has placed in nature of man the tendency to both good and evil. He has been awarded the ability to distinguish between right and wrong. ${ }^{6}$

Keeping in view the dual nature of human personality, Islamic concept of motivation includes spiritual motives in addition to psychobiological motives that determine human behaviour. The inclusions of religious and spiritual motives provide novel avenues to the research in human motivation theory and practice. ${ }^{7}$ Western concept of motivation is based upon relationship between an individual and his work organization or the society, whereas an Islamic perspective of motivation sees motivation as a relationship between an individual and his Lord (Allah Almighty). This difference creates number of distinctions between Western and Islamic concept of motivation. Through careful study of the Quran and Sunnah of the Holy Prophet Muhammad (SAW) some salient features of Islamic motivation theory are outlined in the following:

\footnotetext{
${ }^{1}$ Al-Tīn: 4

${ }^{2}$ Al-Sajdah: 9

${ }^{3}$ Naqvi, Ethics and Economics: An Islamic Synthesis, p:45

${ }^{4}$ Mūsa Sadr, Islam: Humanity and Human Values, p:31

${ }^{5}$ Al-Shams: 7-8

${ }^{6}$ Al-Balad: 10

${ }^{7}$ Alawneh, S. F., Human Motivation: An Islamic Perspective, The American Journal of Islamic Social Science, 15 (4), (1999), PP: 25
} 
$\bar{I} Q \bar{A} N$ : Vol: 02, Issue: 03, Dec 2019

\section{Guidance from Holy Quran and Sunnah:}

In contrast to Western theories of motivation, in Islam the most important element in a person's motivation are those values that are derived from the commandments of Allah. In Muslim faith the Quran and Sunnah of the Prophet (SAW) serve as guide to all human endeavours. Holy Quran, according to Islamic beliefs is the 'Word of God' and builds theoretical and practical framework for all human activities. Quran identifies itself as a complete and final form of message of Allah sent to mankind through Prophet-hood of Muhammad (SAW). ${ }^{1}$ In the motivational context, although the Quran is not book of psychology; however, it provides in depth insight into the nature of man and his conduct in this world. ${ }^{2}$ Man is invested with the ability to judge between right and wrong, however, to reinforce this realization Prophets (AS) are sent by Allah in every community and in every age. The Prophets (AS) were sent as guide for humanity to declare the reward and punishment system for their deeds. ${ }^{3}$ The personality of the Prophet (SAW) serves as most excellent and perfect guide in lives of Muslims. Holy Quran describes:

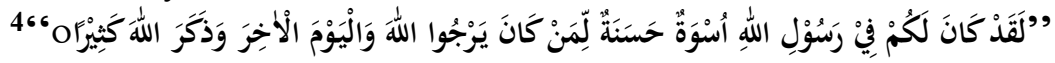

"There is indeed a good model for you in the Messenger of Allah for the one who has hope in Allah and the Last Day, and remembers Allah profusely."

The Quran describes that Prophet Muhammad is ideal not only for past, but also for present, but for all generations. His exemplary conduct is beyond the limits of time and space. ${ }^{5}$ This is for the reason Muslims seeks guidance from Holy Quran and Sunnah of the Prophet (SAW) in all matters of life. In formulating motivation theory a Muslim firstly seeks guidance from Holy Quran and Holy Prophet. In motivation theories the role of ideal personality is very important. The personality of the Prophet Muhammad is praiseworthy as a perfect motivator and mentor. So in the first instance, the distinctive feature of Islamic knowledge is that it derives its inspiration from Divine sources while conventional motivation theories contends itself on human reason, intellect and experience.

\footnotetext{
${ }^{1}$ Al-Māidah: 3; Al-Baqarah: 2; Al-A'rāf: 158

2 Al-Tīn: 4; Al-Hijr: 29; Tā-Hā: 122; Al-Dahar: 3; Al Baqarah: 31; Al-Baqarah: 38; Al-Isrā: 70; Al-Shams: 7-8; Adh-Dhāriyāt: 56; Al-Hashr: 19 and various other verses of Quran.

${ }^{3}$ This notion has been explained in various verses of the Quran, for example:

Fātir: 24; Al-Baqarah: 119; Saba: 28

${ }^{4}$ Al-Ahzāb: 21

${ }^{5}$ Al-Attas, Muhammad Naquīb, Islam, Secularism and the Philosophy of the Future, (New York: Mansell Publishing Limited, 1985), p: 87
} 


\section{Reward and Punishment as Determinant of Motivation:}

The whole life of a Muslim is test from Allah. All activities of human beings are judged by Allah to know their conformity with the Will of Allah. All human beings are expected to perform best of their ability according to the instructions of Allah. The Holy Quran declares:

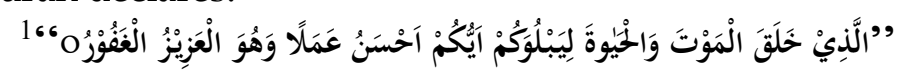

"The One who created death and life, so that He may test you as to which of you is better in his deeds. And He is the All-Mighty, the MostForgiving."

The message of Allah has always been accompanied with the motivation to follow the righteous and abdicate the evil. Muslims strive willingly to perform their duties according to the gratification of Allah. This serves as a strong motivation for Muslims that all their actions are watched and judged by the Almighty Lord. However, to strengthen this feeling Islam motivate people with reward and punishment system. For good deeds Muslims are given surety of blessings in this world and in the Hereafter. In contrast to it, in case of wrong doings people are warned of punishment not only in this world but also in the hereafter. There are number of verses of Holy Quran that shed light on this topic:

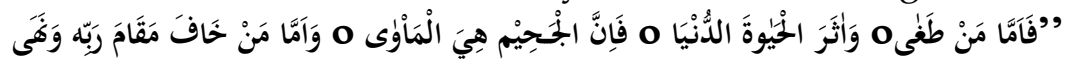

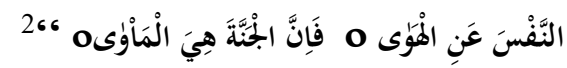

"Then for the one who had rebelled, and preferred the worldly life (to the Hereafter), the Hell will be the abode, whereas for the one who feared to stand before his Lord, and restrained his self from the (evil) desire the paradise will be the abode."

There are two elements of the punishment and the reward; on the one hand it creates inspiration among people to do good deeds, and on the other it pushes one back with the fear of punishment. Moreover, reward and punishment in Islam is that of transcendental nature. It is not confined to the material gains and losses, its impact go a long way to the consequences of actions in the hereafter. ${ }^{3}$

\section{Pleasure of Allah Almighty-the Ultimate objective of Life:}

Goal setting is very important aspect of human motivation. A man is motivated by his personal aims and objectives. The higher the goals are the more effective human performance is expected. Modern motivational theories keep material

\footnotetext{
${ }^{1}$ Al-Mulk: 2

${ }^{2}$ Al-Naziaat: $37-41$

${ }^{3}$ Al-Ra'ad: 25; Muhammad: 22-23; Ībrah̄̄1m: 7
} 
$\bar{I} Q \bar{A} N$ : Vol: 02, Issue: 03, Dec 2019

objectives in front to motivate individuals. Islam keeps different point of view regarding objectives of life. According to the Holy Quran:

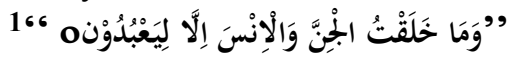

"I did not create the Jinns and the human beings except for the purpose that they should worship me."

In Islamic world view main motivation of a person is submission to his Lord. ${ }^{2}$ The consciousness of surrender to Allah in every walk of life gives meaning and purpose to human life. It gives direction to human activities and serves as strong motivator to live a decisive life. In the above verse Allah Almighty ordained that 'Human beings' and 'Jinns" should serve Him, for He is their Creator. This is the sole objective of life of both creatures. The word 'Ibadah' does not confine to the religious rituals such as prayer, fasting and other forms of worship, it extends to the whole life of human beings. In the terminology of the Quran the word 'Ibadah' is used in its complete sense. Human beings must carry out the orders of Allah in whole of their lives. ${ }^{3}$ This concept of worship of Allah manifests itself into the attainment of His pleasure. Therefore, the objective of attainment of Pleasure of Allah is another motivator factor that stems from the Islamic concept of worship. The main purpose of life of an individual is to transform himself into a person with whom Allah is pleased. Allah Almighty declares it as the greatest blessing which has no parallel in the entire universe:

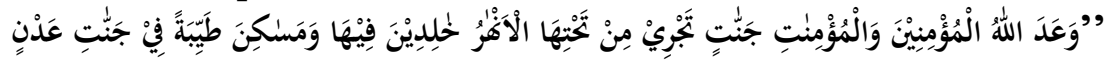

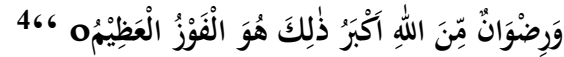

"Allah has promised the believing men and believing women Gardens beneath which rivers flow. They shall abide in it. There are delightful dwelling places for them in the Gardens of Eternity. They shall, above all, enjoy the good pleasure of Allah. That is the great achievement."

The everlasting life of gardens of heaven, added with the attainment of pleasure of Allah has been declared as the greatest achievement of human life. This goal of achievement of pleasure of Allah added with the rewards of the hereafter, keeps the believers alive and enthusiastic to perform best of his potentials. It has been mentioned in the Quran:

\footnotetext{
${ }^{1}$ Al-Zariyāt: 56

${ }^{2}$ Labīb Al-Saeed, (Urdu trans.), Islami Riyasat main Musalmanon ke Huqooq-o-Faraiz aur Islam ka Baldiyati Nizam, (Lahore: Islamic Publications Ltd., 1976), p:13

${ }^{3}$ Maudūdi, Abul A'la, Tafheem-ul-Quran, (Lahore: Idara Tarjuman-ul-Quran, 1994), Vol: 5, p: $155-156$

${ }^{4}$ Al-Tāuba: 72
} 


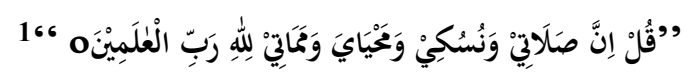

"Say: my prayer, my offering, my life and my death are for Allah, the Lord of all the worlds."

The verse endorses that final objective of all human endeavors according to Quran is to achieve love of Allah through good deeds. This goal of life can be achieved with a strong belief system. Complete faith in Allah makes the man focused on his objective of life. ${ }^{2}$

In sum, the highest level of Islamic motivation is the attainment of 'Pleasure of Allah' and rewards of the 'Hereafter'. A man requires an ideal to follow his footprints to achieve performance excellence that may please Allah. To fulfill this basic human need Allah has sent his Messenger to provide an ideal conduct for humanity. Allah Almighty has assigned duty to the Prophet Muhammad to motivate people on best of their deeds. The methodology of Prophet Muhammad to carry out this task is discussed.

\section{Prophetic (SAW) Methodology of Motivation:}

Motivation is a goal oriented process that reflects a person's attitude to behave in a certain way. It is a behavior that shows willingness to follow a certain pattern of life. In the process of motivation person psychologically require a goal ahead or personality in focus to follow him. It calls for a complete model to be followed. This model acts as a silent preacher who inspires and attracts other people towards himself. The Holy Quran declares in that life of the Prophet Muhammad (SAW) is best example for Muslims:

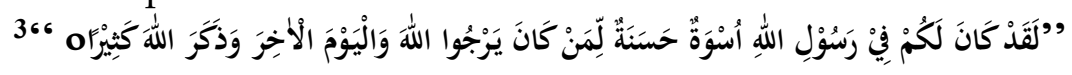

"There is indeed a good model for you in the Messenger of Allah - for the one who has hope in Allah and the Last Day, and remembers Allah profusely."

Although this verse was revealed in special context to the war of trench; however, its meanings are general to all circumstances. ${ }^{4}$ The character of Prophet Muhammad (SAW) was such that it exhibited the best example for Muslims. The Muslims are required to follow the personality of their Prophet (SAW) in all

\footnotetext{
${ }^{1}$ Al-Anām: 62

${ }^{2}$ Ghauri, Muhammad Tariq, Religious Motivation: A Multiplying Force, The Dialogue, 4 (2) (2011): PP: 110

${ }^{3}$ Al-Ahzāb: 21

${ }^{4}$ Al-Shawkāni, Muhammad Ibn Ali, Tafsir Fath-ul-Qadīr, (Beirut: Dar al-Kutub al-Ilmiyah, 2003), Vol: 4, p: 271
} 
$\bar{I} Q \bar{A} N$ : Vol: 02, Issue: 03, Dec 2019

circumstances. In motivational context, among other duties of the Prophet (SAW), Quran has described his role as a motivator:

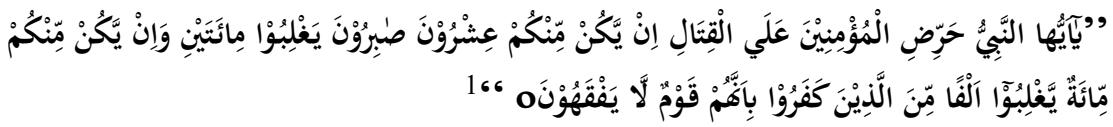

"O Prophet, rouse the believers to fighting. If there are twenty among you, who are patient, they will overcome two hundred; and if there are one hundred among you, they will overcome one thousands of those who disbelieve ,because they are a people who do not understand."

The Prophet (SAW) is ordained to motivate people on war. This is the meaning of the verse in the context; however, the general meanings of this verse are not limited to the conditions of war. In all circumstances the Prophet Muhammad (SAW) aroused Muslims to put best of their efforts in the way of Allah. Prophet Muhammad (SAW) stimulated the Muslims such that they were ready even to sacrifice their lives at all times. Here in after the methodology of Prophet Muhammad (SAW) to motivate his followers is presented. Whole life of the Prophet (SAW) is source of inspiration and motivation for Muslims. However, there are many examples to describe methodology of Prophet (SAW) to motivating people, but we mentioned some these famous;

\section{Leading from the Front:}

The first motivating method used by Prophet (SAW) was to set an example for others through his own conduct. He was not the preacher of empty words. He at first used to obey the order of Allah and then ask Muslims to follow it. The Prophet (SAW) always implemented the teachings of Quran to his life in true letter and spirit. His private and public life was a living picture of the Holy Quran. Once Ayesha (R.A) was asked about the manners of the Prophet, she replied:

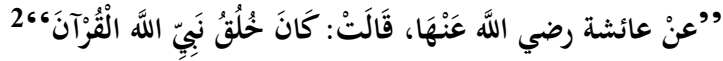

"Narrated from Ayesha: the manners of Prophet were (just like) Quran"

This tradition reveals the fact that life of the Prophet (SAW) was in complete accordance with the teachings of Quran whether in private or in public. The practice of Prophet on teachings of Quran motivated his followers to submit before the ordainments of Quran. He asked people to worship their Lord and offer prayers to seek His Pleasure. He himself practiced it more than anyone else.

\footnotetext{
${ }^{1}$ Al-Anfāl: 65

${ }^{2}$ Al-qushāirī, Muslim bin al-Hajjaj, Al-Jam'e al-Sahih, (Al-Riyadh: Dar-us-Salam, 2000), h: 1847
} 


$$
\text { شكورانهان النبي صلى الله عليه وسلم يصلي حتى ترم أو تننفخ قدماه فيقال له فيقول أفلا أكون عبدا }
$$

"The Prophet used to pray so much that his feet used to become edematous or swollen, and when he was asked as to why he prays so much, he would say, Shall I not be a thankful slave (to Allah)?"

This is an example of leader who leads in front. In the famous war of "Khandaq" the process of digging the trench was ongoing, a companion of Prophet (SAW) complained about hunger and show him a stone tied with his belly. In reply Prophet did not say something; instead he showed the complainer his own belly where two stones were tied to bear hunger. ${ }^{2}$ Moreover, to motivate others he used to do ordinary works with his own hands. Once at night in Madinah, a frightened noise was heard. All residents became scary and come out of their houses. It is narrated on the authority of Anas (R.A):

$$
\text { فركبه فقال ما رأينا من فنع وإن وجدان بالمدينة فنع لبحرار الببي صلى الله عليه وسلم فرسا لأبي طلحة يقال له مندوب }
$$

"Anas reported that there was consternation in Medina. The Messenger of Allah (May peace be upon him) borrowed the horse from Abu Talha which was called Mandub. He rode it and said: We have found no reason for consternation, and we have found it to be (as quick as a torrent) of water."

To become example for the subordinate is the first and foremost method of inspiration. This methodology can be proved beneficial in every area of life and in all circumstances.

\section{Material Rewards:}

The material aspect of life is common between animals and human beings. The material needs such as food, drink, air, shelter, etc. are common between human beings and animals. Islam acknowledges the material needs of human beings and uses them as motivating factors. Offering material rewards to motivate people is a strategy that is described in the Quran. In the Quran the incident of Pharaoh has been described to use of material resources as motivator factor:

\footnotetext{
${ }^{1}$ Al-Bukhāri, Muhammad bin Ismāil, Al-Jām'e, al-Sahih, (Riyadh; Dar-us-Salam, 1999), h: 1130

${ }^{2}$ Al-Tirmiz̄̄ , Muhammad bin Īsā, Al-Jām'e, (Al-Riyadh: Dar-us-Salam, 1999), h: 2371

${ }^{3}$ Muslim, Al-Sahih, h: 2307
} 
$\bar{I} Q \bar{A} N$ : Vol: 02, Issue: 03, Dec 2019

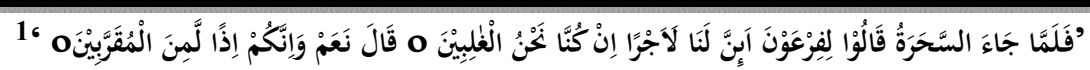

"So, when the sorcerers came, they said to Pharaoh, Will there be a sure reward for us, if we are the victorious? He said: Yes, and of course, you will then be among the closer ones."

The Pharaoh promised the magicians to give more wealth than the agreed upon amount in case of victory over Prophet Mosa (A.S). Also the holy Prophet Muhammad (SAW) randomly used to give charities and other material rewards to newly embracing Muslims. The level of his spending was such that people used to speak out:

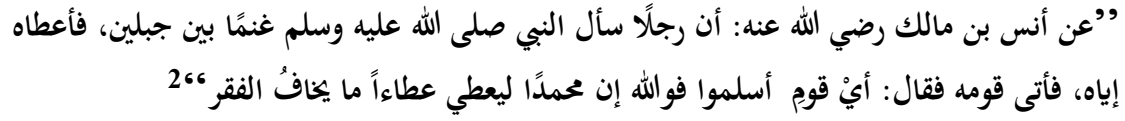

"Anas bin malik reported: a man came to holy prophet (saw) and asked him for flock of goats and he gave him. Then he went back to his people and said: my people, embrace Islam, for Muhammad gives so much charity as if he has no fear of poverty."

Besides giving charity, holy Prophet (SAW) used to pay wages to the administrators and collectors:

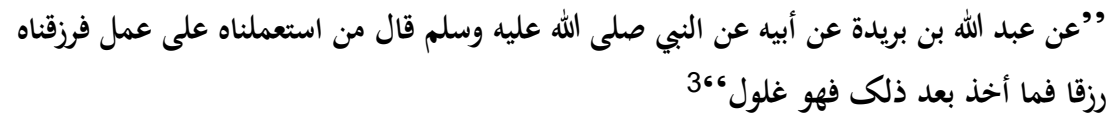

"It was reported from 'Abdullah bin Buraidah, from his father, from the

Prophet, who said: If we appoint somebody to do any (administrative)

work and grant him a provision, anything he takes beyond that is

Ghulul."

Moreover, the Prophet (SAW) offered rewards to the services he used for himself. Once he was cupped and he paid for it:

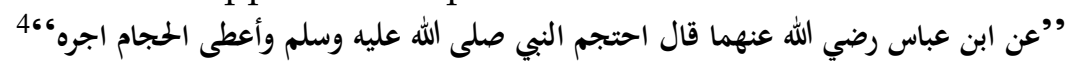

"Narrated Ibn 'Abbas: When the Prophet was cupped, he paid the man who cupped him his wages."

This signifies the importance of material rewards. Besides salary remuneration, bonuses and other material rewards must be offered to keep work people motivated.

\section{Non-Material Motives:}

The non-material rewards are also used by Holy Prophet (SAW) to motivate

\footnotetext{
${ }^{1}$ Al-Shu'ara: 41-42

${ }^{2}$ Muslim, Al-Sahih, h: 2312

${ }^{3}$ Al-Sījistāni, Suleman bin Ash'ath, Al-Sunan, (Al-Riyadh; Dar-us-Salam, 1999), h: 2943

${ }^{4}$ Al-Bukhāri, Al-Sahih, h: 2278
} 
people. Two most significant motives in the lives of Muslims are: Pleasure of Allah and Paradise. ${ }^{1}$

In Islam work is not only a source of earning livelihood but it is also a form of worship. Monetary reward is not the ultimate purpose and objective of life for Muslims; rather they are more motivated by non-material rewards. ${ }^{2}$ The Prophet (SAW) used benefits of hereafter effectively to inspire Muslims. In the early days of Prophecy Muslims were subject to torture and extreme difficulties of life. Once the Prophet saw his followers Ammar bin Yasir and his family tortured by infidels. He said to Ammar and his family:

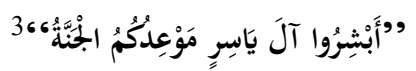

"Good news is for family of Yasir: You are promised with Paradise"

This methodology of motivating people worked so effectively that people even sacrificed their lives delightfully.

\section{Praise and Tribute:}

The Prophet (SAW) was very generous in praising and admiring the good deeds of his followers. He used the principle of giving praise and encouragement for inspiring his companions so that they perform better.

The preparation of war of 'Tabük' was started when Muslims were very poor and hand to mouth. Usman (R.A) spent a large amount of money in this noble cause. The Prophet Muhammad (SAW) appraised him in this way:

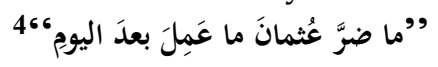

"Nothing will harm 'Uthman after today whatever he does."

This praise was to motivate other people to spend in the way of Allah. An Ansari companion earned four KG's of dry dates, kept two kilos for family and gives two kilos to the way of Allah at the time of "Tabuk". For the sake of his encouragement and motivation of others the Prophet (SAW) said to him that "Spread them on the alms."

This is just an example how the Prophet (SAW) motivated and inspired his

\footnotetext{
${ }^{1}$ Salleh, Mohamad Johdi, \& N. Mohamad. "Islamic principles of administration: Implications on practices in organization." In Technology, Science, Social Sciences and Humanities International Conference, Langkawi, Malaysia. (2012): PP: 4

${ }^{2}$ Azmi, Ilhaamie Abdul Ghani. "Human capital development and organizational performance: a focus on Islamic perspective." Syariah Journal, 17 (2), (2009): p: 360

${ }^{3}$ Al-Hakim, Abu Abdullah Al-Hakim, Al-Mustadrik 'alal-Sahihain, (Cairo: Darul Harmain, n.d.), Vol:3, p:388-389

${ }^{4}$ Al-Tirmizi, Al-Jame, h: 3701
} 
$\bar{I} Q \bar{A} N$ : Vol: 02, Issue: 03, Dec 2019

companions to put their excellent abilities in the way of Allah. On the other hand, Holy Prophet (SAW) used to praise the qualities of people to motivate them. One example is quoted here of a person named "Ashajj" of delegation of Abdul-Qais. The Prophet (SAW) has been reported to have said to Ashajj:

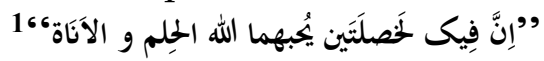

"You possess two qualities which are liked by Allah: insight and deliberateness."

The Holy Prophet not only motivated one person but its effect was on collective minds of that delegation. The praise and tribute presented to their leader effectively inspired them and they become more faithful to Islam.

\section{Examples Before Islam:}

Stories and fantasies inspire people and make their mind on a certain issue. The Quran and Sunnah used human history very frequently to arouse people on good deeds and warn them the consequences of bad deeds. When some thoughts or point of view are described in the form of a narrative it affects the minds of listeners and trigger off their hidden capacities and capabilities. There are number of narrations mentioned in the books of Ahadith with which Prophet (SAW) instigated the feelings and aspirations of companions. For example it is narrated on the authority of Khabab bin al-Art:

$$
\begin{aligned}
& \text { "فعن خباب بن الأرت قال: شكونا إلى رسول الله }
\end{aligned}
$$

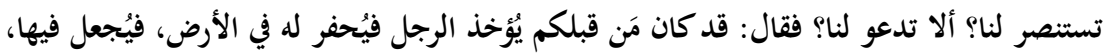

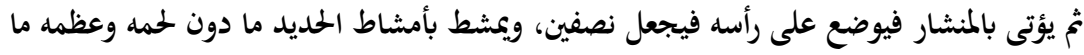

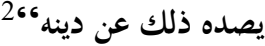

"Narrated Khabbab bin Al-Arat: We complained to Allah's Messenger (about our state) while he was leaning against his Burda (cloak) in the shade of the ka'bah. We said, "Will you ask Allah to help us? Will you invoke Allah for us? "He said, "Among those who were before you, a (believer) used to be seized and a pit used to be dug for him and then he used to be placed in it. Then a saw used to be brought and put on his head which would be split into two halves. His flesh might be combed with iron combs and removed from his bones, yet, all that did not cause him to revert from his religion.

This tradition of the Prophet (SAW) manifests itself in dual motivation process. Firstly it inspires believers from the attitude of previous believers on account of how they become determined in the way of Allah.

\footnotetext{
${ }^{1}$ Muslim, Al-Sahih, h: 18

${ }^{2}$ Al-Bukhāri, Al-Sahih, h: 6943
} 
And secondly, it gives motivation to be determined in the right path for the hope of good future.

\section{Concern of Hereafter:}

Concern of hereafter makes a man more conscious than a man who believes in this material world only. The concept of accountability in interrelated with concern of hereafter. The Holy Prophet (SAW) used the concept of hereafter to motivate the people on doing well and forbidding wrong. He used to warn different kind of punishments on the wrong doings so that people abstain from them and strive for good deeds. The concept of final accountability changes the frame of mind of individuals. Through this concept the life on this earth is perceived as a chance to perform better to succeed in the life after death. The Prophet used the belief on final accountability and concern of hereafter to convince people to refrain from bad behaviors and said:

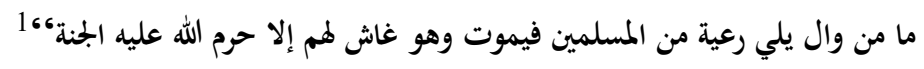

"If any ruler having the authority to rule Muslim subjects dies while he is deceiving them, Allah will forbid Paradise for him"

The loss of Paradise due to some bad behaviors is regarded as high risk for Muslims. This produces a deep sense of responsibility among Muslims. For example he reminded Muslims that they are responsible for their own conduct and conduct of their subordinates: The Holy Prophet Muhammad (SAW) has been reported to have said:

$$
\begin{aligned}
& \text { ”عن عبد الله بن عمر رضي الله عنهما أنه سمع رسول الله صلى الله عليه وسلم يقول كلكم راع }
\end{aligned}
$$

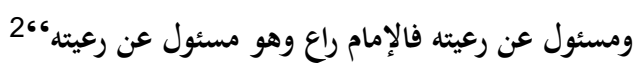

"Narrated Abdullah bin 'Umar(RA): I heard Holy prophet (SAW)

saying, every one of you is a guardian, and responsible for what is in his

custody. The ruler is a guardian of his subjects and responsible for them."

The Holy Prophet (SAW) reminded it continuously to Muslims that they are not left free; rather they are under strict supervision of their Lord, and are responsible on the Day of Judgment. This act as strong motivator to do best of their ability and abandon something that is not desirable in the court of Allah.

\section{Use of Human Psyche:}

Motivation is psychological phenomenon and is a state of mind. Recent studies have shown that human feelings and work environment play an important role

\footnotetext{
${ }^{1}$ Al-Bukhāri, Al-Sahih, h: 7151

2ibid, h: 2409
} 
$\bar{I} Q \bar{A} N$ : Vol: 02, Issue: 03, Dec 2019

in the motivation level of work people. The Holy Prophet effectively used human feelings of his companions to stir up their minds and instigate them on performance excellence. He was fully aware of psyche of each of his companion, his weakness and his good qualities. He normally used to consider the state of mind of each individual and respond to him according to his needs. It is evident from the books of Ahadith that different people came and they ask the same question but the Prophet (SAW) replied to them with different answers. This shows that the Prophet (SAW) considered the psyche of each individual and answered him the most appropriate solution to his problem. ${ }^{1}$ In the same context, at the victory of Makkah he declared that the one who will take refuge in the house of Abu Sufyan (RA) shall be pardoned. Abu Sufyan (R.A) was given this honor because the Prophet (SAW) knew it very well that Abu Sufyan (RA) is the person who likes to be honored. To motivate him and satisfy him he gave him such honor. Another famous incident is that of Hunain. After the battle of Hunain Prophet distributed the spoils of war into tribes of Arab and ignored Ansar of Madinah. Ansar were not satisfied with this distribution. When Prophet heard of this, he gathered Ansar and makes a long speech to them. In the end he said:

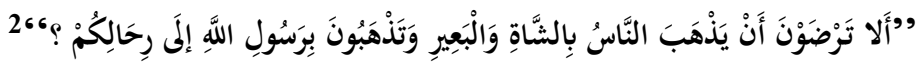

"Do you not accept that people go with sheep and camels, and you go back with the Messenger of Allah to your journey?"

This phrase inspired people of Ansar such that they start weeping and said: "we are happy with the disbursement made by Prophet of Allah (SAW)." This is the best method used to engage people and keep them motivated. This tradition and many other traditions of Prophet Muhammad (SAW) are witnessed on the quality of Prophet Muhammad (SAW) to use the feelings, aspirations and sentiments of people to motivate them.

\section{Optimism:}

Motivation level is decreased in negative state of mind. A pessimistic person cannot work with full energy. To motivate people it is necessary that they are filled with hope and enthusiasm. The Prophet Muhammad (SAW) used this characteristic of human behavior in profound manner. He kept his followers optimistic in extreme circumstances. When Muslims were facing extreme difficulties and torture from Infidels of Makkah, the Holy Prophet gave them hope of good future. In the early days of Prophet-hood he foretold the victory of Islam:

${ }^{1}$ Al-Bukhāri, Al-Sahih, h: 2518,\& h: 2782

${ }^{2}$ Ibid, h: 4330 


$$
\text { غنمه ولكنكم تسنعنّ الله هذا الأمر حتى يسير الكاكب من صنعاء إلى حضرموت لا يخاف إلا الله والذئبَ على }
$$

"By God, God wishes for this until the passenger walks from Sanaa to Hadhramout and he will not have fear but only of God and of wolf for his sheep, but you are in a hurry"

Optimism is the quality in human beings which creates an environment of hope for favorable outcomes and expectancy of the best in all circumstances. Optimism electrifies a person and makes him such that he takes his work seriously and completes it well and rapidly. Optimism discourage lethargic attitude and promotes diligence in human endeavors. It makes a man more active and paves a way for his success and helps in achieving his goals.

\section{Moderation:}

And finally, the Prophetic (SAW) methodology of motivation was based on the principle of kindness and leniency. He used to be gentle with others and ordered others to make matters of life easy for others. He did not like extreme behaviors. He insisted on moderate but steady course of action. He has been reported to have said:

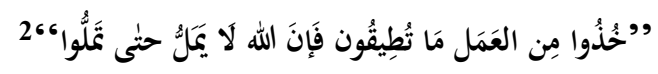

"Do those deeds which you can do easily, as Allah will not get tired (of giving rewards) till you get bored and tired (of performing religious deeds)."

The philosophy behind this saying is that if a job is started with extra zeal and flair, sooner or later motivation level of this movement start decreasing. If there is moderate behavior adopted there are more chances that the motivation level will increase day by day or will remain constant. It has been endorsed in another statement of Prophet Muhammad (SAW):

$$
\text { "وأن أحب الأعمال إلى الله أدومها وإن قل،3، }
$$

"And that the most beloved deed to Allah's is the most regular and constant even though it were little."

It is very clear from this tradition of the Holy Prophet (SAW) that to maintain a minimum level of motivation a steady course of action is required. Thus, the Prophet (SAW) used the method of moderation and steadiness to keep his

\footnotetext{
${ }^{1}$ Al-Bukhāri, Al-Sahih, h: 6943

2ibid, h:1970

${ }^{3}$ Ibid, h: 6464
} 
$\bar{I} Q \bar{A} N$ : Vol: 02, Issue: 03, Dec 2019

companions motivated and consistent with their dealings. In the above, some methods and techniques of Prophet (SAW) are presented to show the variety of motives he used to inspire and encourage his fellow beings. The determinants of motivation used by Prophet of Islam (SAW) vary from material to non-material. He kept in mind the real purpose of man and prepared them to achieve their desired goals of life. In doing so he effectively used the psychological feelings and aspirations of human beings to bring into play best of their capacities. These methods are beyond the limits of time and space and can be applied today without any hesitation.

\section{Results:}

The study provides following results:

1. Western motivational theories are based upon secularist and materialistic view of man and his needs. The modern theories of motivation are focused on enhancing human capability through material rewards and change in work environment. The role of religion is neglected in these theories. Religion plays vital role in some parts of the world especially in Muslim countries. As part of cultural baggage the religious values are carried with the persons.

2. Islam is a distinct religion and provides its unique view point regarding this world and role of human beings in this universe. Moreover, it provides deep insight into human psyche, his aspirations, and true goals and objectives of life. According to Islamic teachings being two dimensional being, man is motivated by both material as well as non-material rewards added with the ultimate goal of attainment of Pleasure of Allah. All these concepts change the determinants of motivation. Islam maintains balance between material and non-material rewards and creates equilibrium in human personality through positive motivators.

3. The Prophet of Islam (SAW) translated Islamic theory of motivation into practice and adopted a distinct methodology to motivate his companions and related persons. The Prophetic methods of motivation use human psyche at its optimum level. He used various techniques to inspire and encourage people to do best of their ability and attain excellence. Some of his methods include, leading from the front, use of material and non-material rewards, concern of the hereafter and accountability on the Day of Judgment etc.

\section{Recommendations:}

In the light of study following recommendations are presented:

1. Education system of Islamic countries is usually based on Western pattern. In Pakistan the education system at higher level, is based upon Western research. Islamic values and guidelines are neglected dimension of educational syllabus of Pakistani educational institutes. There is need to include Islamic perspective of related subjects with reference to human motivation and capacity building. 
2. Motivation from an Islamic perspective is relatively new to academia; more research is required on its different aspects. This study provides an initial blue print of Prophetic motivation, other possible areas of research in this field include: Islamic work values and their effect on motivation, Types of motivations determinants in Islam, Islamic motivation and its impact on human performance.

3. A team of researchers comprising of educationists, social scientists, and Islamic scholars must work together to find out framework of motivation in the present day environment.

\section{Conclusion:}

The recent developments observed in the world are owed to the efforts of human capacities and capabilities. Zeal, flair and enthusiasm of work people keep the pace of development in steady mode. However, over a period of time, human motivation to work starts decreasing. In the Western World studies have been carried out to find out factors which affect human motivation to devise strategies to enhance work motivation among individuals. It has been observed that determinants of motivation are cultural specific. Moreover it is associated with the world view of man. Islam is different religion from other religions of the world and forms its own culture. Holy Prophet Muhammad (SAW) in his life time prepared a group of individuals who changed the socio-political scene of this world in few years. Their motivation level was un-parallel to anyone else. The current study explores methodologies of motivation used by the Prophet (SAW) to stimulate his companions. The originality and value of this study can be seen in the sense that it will provide basis for the formulation of motivational framework based on Islamic teachings. As a conclusion, team of researchers comprising of educationists, social scientists, and Islamic scholars must work together to find out framework of motivation in the present day environment. The progress and development of world in socio-economic fields, in technology, and all other areas of life is due to competent and responsible workforce. Motivational theories presented by Western scholars are really beneficial for motivating work people and enhancing their productivity. But all these theories are based upon materialistic philosophy of life. The spiritual being of humans is totally ignored in these theories.

(a) 2019 by the author, this article is an open access article distributed Under the terms and conditions of the Creative Commons Attribution (CC BY) (http://creativecommons.org/licenses/by/4.0/) 